Volume 8, No.5, September - October 2019

International Journal of Advanced Trends in Computer Science and Engineering

Available Online at http://www.warse.org/IJATCSE/static/pdf/file/ijatcse17852019.pdf

https://doi.org/10.30534/ijatcse/2019/17852019

\title{
The Influence of Social Media and Knowledge Management to Improve Employees Creativity
}

\author{
Gunawan Wang $^{1}$, Laras Anggita Destofia ${ }^{2}$, Fakhri Nurullah ${ }^{3}$, Devi Yurisca Bernanda ${ }^{4}$ \\ 1,2,3 Information Systems Management Department, BINUS Graduate Program-Master of Information Systems \\ Management, Bina Nusantara University, Jakarta, Indonesia 11480. \\ E-mail: gwang@binus.edu¹, laras-destofia@binus.ac.id ${ }^{2}$, fakhri@binus.ac.id ${ }^{3}$ \\ ${ }^{4}$ Department of Information System, Universitas Bunda Mulia, Jakarta, Indonesia 14430. \\ Email: dbernanda@bundamulia.ac.id ${ }^{4}$
}

\begin{abstract}
The active participation of employees in supporting company or organization operations is necessary to achieve corporate objectives. Increasing employee knowledge in the problem-solving process enable to deliver major impact on company innovation to compete with competitors. The use of Knowledge Management (KM) enables to gather process of to identify, to organize, to store and to reuse knowledge to improve organizational performance. Its association with elements of social media makes the collaboration of these two tools highly relevant to enhance employee creativity. The results of this paper show that results that social media has a close relationship with knowledge management to improve employee creativity and create innovation for the company is running business operations.
\end{abstract}

Key words: knowledge management, social media, employee creativity, innovation.

\section{INTRODUCTION}

The modern thinking of an organization or company has realized the potential that arises from the integration of flexible information, with the use of various to interactive and to collaborative tools today. Effective identification, the use of data and information and knowledge has become the organization's or company's top priority in establishing itself as a proposition to gain collaborative excellence, sustainable growth, and prosperity for employees as well as all corporate partners [1]. This knowledge Becomes a very valuable [2], the value increasing process of a company or organization is required as supporting of resources management-owned properly, one of which is knowledge management. According to Hurley and Green knowledge Management $(\mathrm{KM})$ is defined as a process consisting of the identification, manufacture, retrieval, organizing, storage, and reuse of knowledge to improve organizational performance with effective and efficient use of organizational resources [3]. There are many ways to support knowledge management creation one of which is the social media use. The increasing number of Internet users, especially social media in Indonesia, which continues to increase every year to reach the number of 97.9 million users (Source: Okezone) brings great opportunities to support and create knowledge management. Social media events or phenomena have attracted a lot of attention practitioners and scientific interests in recent times [4]. There is a research scarcity that tests what influences the new tools currently on innovation and business performance [5]. The social media use in a community can be in line with knowledge management concept where the activities of users perform the process of storing, grouping, and connecting information so that it can significantly support the performance of their creativity [6]. In addition, people involved in social media networks also doing the sharing process, discussing and negotiating information with other users in most of the information comes from the tacit knowledge of each user. Tacit knowledge plays a very significant task in increasing the performance of individuals and organizations as well as a competitive advantage [7]. So from the interaction will create an information diversity that can potentially improve user innovation. Based on this, the writing of this journal will focus attention at same time at the analysis of the relationship between knowledge management and social media to increase employees creativity on case studies in Indonesia.

\section{LITERATURE REVIEW}

The specific words, those are used in this paper, are defined the meaning as follow:

\subsection{Knowledge}

Many research discusses the difference between information and knowledge. Information is a representation "to inform" that contains data variety from a particular source and knowledge means representing "to know" something from especially collected information [8]. The knowledge embedded in employee creative mind and desire of each individual to use knowledge systematically encourages the successful use of that knowledge [9].

Sectional knowledge needs to be reviewed in the managing of diverse local environments ranging from employees and divisions [10]. In resource management, the peoples with 
local knowledge have the ability to process accurate decision-making, so methods involving such people need to be addressed in management. Local knowledge can also make a clear contribution to the management of existing resources with a far-sighted perspective [11].

\subsection{Social Media}

Social media has penetrated far into everyday life for internet users, and the increased use of smartphones is reinforcing the incident. Currently, social media use increasingly attached to the support of smartphones that are always in the hands of users [12]. Social media is a place for a set of interactions that are organized based on the user's relational structure and its own relations. Social media is most easily understood as a link that connects the Internet with a fast communication channel, where everyone can express ideas, thoughts and share them together [13].

Among the many types of organizations and companies that have high regard for active users of social media analytics, utilizing social media data to better understand why the phenomenon of customers buying products or services plays a very important role in maintaining a competitive advantage [14]. Similarly, companies or organizations that have a high interest in KM and social media (SM) collaboration will have a competitive collision on employee creativity achievement in running business operations.

\subsection{Knowledge Management}

Knowledge management (KM) expresses the process of to acquired, to floated, to divide, to exploit, and to protect organizational knowledge to enhance competitiveness [15]. Knowledge creation and development is a very important feature or module in knowledge management, knowledge creation may take place in a variety of dynamic and static forms such as through natural and human methods (such as ongoing formal training or talking with people who share your interests or hobbies) or technical mechanisms (activities data mining = DM) [16]. When an employee leaves the company, so knowledge, experience, and insight will be brought by him so much needed knowledge sharing process to be able to capture and share knowledge owned employees to other employees. Therefore, the need of application of KM System to support effective information delivery, KMS consists of hardware, software, people and organizational environment that support the creation, transfer, and dissemination of knowledge between employees [17]. There are three generations of knowledge sharing that is [18] such as:

i. First Generation, It is an effort to understand how the related knowledge can remain scattered and can be used within the company internally by using the traditional way with codification concept.

ii. Second Generation, in this section, the KM approach which focuses on the social component of various facets of knowledge. According to Agerberd that social component is about people way to work together and communicate to share their knowledge. Mentoring and coaching is used as a way to let juniors and seniors work together, this can be used in the most formal way, through knowledge sharing systems, but can also be solved with an exchange of ideas, lunch or other informal face-to-face meetings.

iii. Third Generation, the importance of social media to perform knowledge sharing can touch the whole level of the bottom and above, in addition to reducing physical face-to-face activities so that knowledge sharing can be more done virtually.

\subsection{Social Media Characteristics}

Social media consists of a series or platform of activities that allow people to have relationships, transmit and cooperate, as well as tools including blogs, wikis, and other social networking sites [19]. Base on research by Stowe Boyd that social applications must-have elements: can support the interaction of conversation between the individual with the group, support social feedback, and support social network [20]. According to Boyd that the success of social software is dependent on the low-cost availability, high bandwidth tools, self-motivation, and gregarious and eager users.

\subsection{Social Media Characteristics}

$\mathrm{KM}$ is a structured approach to being able to create, modify, collect, exchange, be able to measure and maintain the existing knowledge in dealing with environmental challenges and creating additional value [21]. $\mathrm{KM}$ also has a close relationship with innovation and performance within the organization [22], so that planned activities, collected in the knowledge management (KM) process, present to crucial role in product renewal achievement [23]. To be valuable for a company or organization, Knowledge Management (KM) should direct to behavioral change and new ideas development, processes, practices, and policies. Increasing the competitiveness of enterprises to be determinant of national economic growth as well. some companies are aware and understand enough to start implementing knowledge management as part of their managerial strengths. In this effort, many obstacles occur, which can prevent the continuation of an effective and efficient process to achieve the desired objective [24]. Technology is one of the innovation births in a company, but technology is also a challenge for the company because of its rapid development gave birth to a larger amount of information causing difficulties in management [25]. An established strategy is needed to overcome these challenges. In general, knowledge management has the goal of capturing and storing data and information in the past and using it again in the present or future to solve new problems that arise, including the development of new products and improvement of existing products [26].

According to Xi Zhang, there are about 7 (seven) types of social media (SM) available: integrated development, creating blogs, creating community content, created sites of social networked, virtual gaming worlds, virtual social worlds, and media of mobile social. Knowledge management can also be classified as three sub-processes: capturing knowledge, sharing learning or knowledge, and applicable 
knowledge. Most exceedingly types of social media (SM) have a stronger connection with giving or distribute knowledge than capturing existing data and knowledge [27].

\subsection{Employee Creativity and Social Media}

Definitively, creativity is a process that develops before innovation. This process involves the articulation of a variety of innovative ideas to be able to solve problems or meet existing needs [28]. Effectiveness in resolve in an organization is very important to influence or depends on the quantity and quality of information that they process before. The competitiveness and development of modern organizations depend on the targeted use of data and information. The reason is, companies increasingly pay attention to the development of efficient information technology in order to monitor the input and output of information [29]. In a digitalization and globalization environment, where the speed of technological progress has established mounting pressure on companies to adjust, modification, and improve to stay competitive advantage. As creative employees, they are asked to help companies in innovating as desired by the organization, it is important for a company to be able to recognize and comprehend how the potency of creative that exists in their workers can be released [30].

In essence, social media can support the exchange of ideas, give opinions, and provide experience by facilitating informal interactions, good connections, and contacts among co-workers [31]. Employees are requested and expected to have ability such as intelligence of emotional and fabrication to exploit their potential in using social media [32]. They are often unlikely to accomplish a well-established knowledge [33]. Social media (SM) is also able to solve a relationship crisis that occurs in the company, its presence is able to erode the bureaucracy in terms of passive submission of opinions become more active [34].

Increased complexity of products and services, rapidly changing market demands, or increased pressure from different groups of people into a trend that requires companies to enact new practices to stay competitive [35]. Employee creativity creates innovation for companies to increase competitiveness to competitors. The innovation culture emphasizes the values, norms, and beliefs that encourage proactively, risk-taking, commitment, and changes that occur in companies [36]. Innovation and ideas can only occur if the company has the capacity to innovate. The ability to carry out ideas and innovations is considered a useful and valuable asset for the organization to be able to provide and be competent to stand a benefit of competitive in the implementation of all strategies carried out [37].

\section{RESEARCH METHOD}

\subsection{Research Purposes}

This research has the purpose to know what factors that can affect employees creativity from social media use for employees who work in the field of IT.

\subsection{Validity and Reliability}

According to Eko Putro Widoyoko that in order to obtain valid and reliable data, the assessment instrument used to measure the object to be assessed both test and non-test must have evidence of validity and reliability. With a valid instrument will produce valid data also or can also be said that if the data generated from a valid instrument, then the instrument is also valid.

While the instrument test is said to be reliable if it gives a fixed or steady (consistent) results if the test repeatedly. Reliable instruments are not necessarily valid; therefore instrument reliability is a very important requirement for testing the validity of existing instruments. Therefore, although existing instruments are generally valid, they are generally reliable, testing the reliability of the instruments required.

\subsection{Hypothesis}

This study adopted from the previous research model conducted by Sirous Panahi, Jason Watson and Helen Partridge which then applied to the case study in Indonesia. In a hypothesis test, we apply survey and document analysis method. The data analysis method was done by using PLS-SEM method (Partial Least Square-Structural Equation Model) and assisted with SmartPLS software in processing data.

In the data collection process, we had delivered the questionnaires to the IT employee who worked in IT-related fields in the Jakarta area. From 500 questionnaires delivered, we got 120 valid responses and qualified for further testing. The hypothesis for the study is summarized in Figure 1.

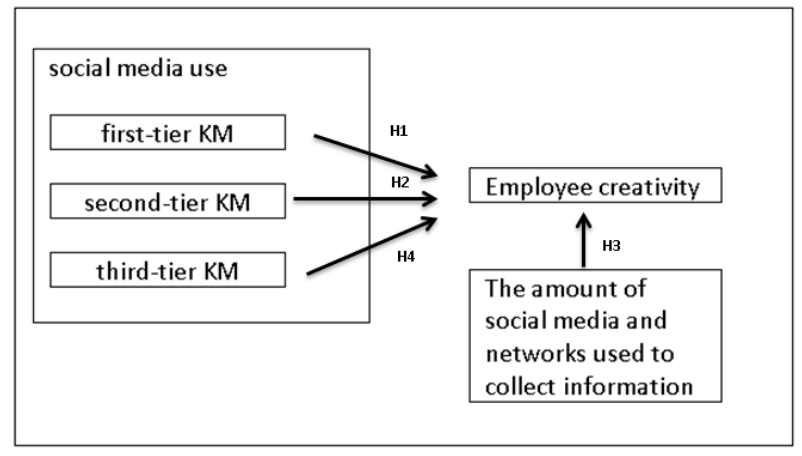

Figure 1: Hypothesis

H1. The social media (SM) use for first-tier Knowledge Management (KM) processes (ie: to search, store and group information) positively related to employee creativity.

H2. The social media (SM) use for second-tier Knowledge Management (KM) processes (ie: can access and can debate information with others) positively related to employee creativity.

H3. Some of social media and networks that can be used to collect or discuss information that is positively related to employee creativity.

H4. The social media (SM) use for third-tier Knowledge Management (KM) processes (ie: to created and produced knowledge) is positively related to employee creativity. The indicators and statements on each variable are: (see Table 1, Table 2, Table 3 and Table 4) 
Table 1: Variable 1: First Level KM Process

\begin{tabular}{|c|c|c|c|c|}
\hline Dimensions & Code Indicator & Indicator & Statement & Inst No. \\
\hline \multirow{4}{*}{ Searching } & \multirow{2}{*}{ A1 } & \multirow{2}{*}{$\begin{array}{l}\text { Ease of data } \\
\text { search. }\end{array}$} & Social media makes it easy to search information & A11 \\
\hline & & & Sources of information gained from the social media use as expected & A12 \\
\hline & \multirow[b]{2}{*}{$\mathrm{A} 2$} & \multirow[b]{2}{*}{$\begin{array}{l}\text { Speed in } \\
\text { data search }\end{array}$} & It does not take long to search the data & A21 \\
\hline & & & $\begin{array}{l}\text { By using social media can display a variety of information sources in } \\
\text { a short time }\end{array}$ & A22 \\
\hline \multirow{3}{*}{ Storing } & \multirow{3}{*}{ A3 } & \multirow{3}{*}{$\begin{array}{l}\text { Collecting } \\
\text { information }\end{array}$} & Use social media to gather information & A31 \\
\hline & & & Uploading information online for personal use & A32 \\
\hline & & & Uploading online information for general use & A33 \\
\hline \multirow{2}{*}{$\begin{array}{l}\text { Categorizin } \\
\mathrm{g} \\
\text { Information }\end{array}$} & \multirow{2}{*}{ A4 } & \multirow{2}{*}{$\begin{array}{l}\text { Codification } \\
\text { information }\end{array}$} & $\begin{array}{l}\text { Generate a code of uploaded information to make it easier to search } \\
\text { data, such as hashtags }\end{array}$ & A41 \\
\hline & & & Easy to search data by input or search by code or certain sign & A42 \\
\hline
\end{tabular}

Table 2: Variable 2: Second Level KM Process

\begin{tabular}{|c|c|c|c|c|}
\hline Dimensions & Code Indicator & Indicator & Statement & $\begin{array}{l}\text { Inst } \\
\text { No. }\end{array}$ \\
\hline \multirow{2}{*}{$\begin{array}{c}\text { Accessing } \\
\text { Informatio } \\
n\end{array}$} & \multirow[b]{2}{*}{ B1 } & \multirow{2}{*}{$\begin{array}{c}\text { Ease of } \\
\text { access to } \\
\text { informatio } \\
n\end{array}$} & With social media there is no place boundary in accessing information & B11 \\
\hline & & & With social media there is no time limit in accessing information & B12 \\
\hline \multirow{3}{*}{$\begin{array}{c}\text { Debating } \\
\text { informatio } \\
n\end{array}$} & \multirow{3}{*}{ B2 } & \multirow{3}{*}{ Discussion } & $\begin{array}{l}\text { Participate in online discussions for the purpose of finding } \\
\text { troubleshooting }\end{array}$ & B21 \\
\hline & & & Comparative knowledge to create new knowledge & $\mathrm{B} 22$ \\
\hline & & & Knowledge sharing to conduct the discussion process. & $\mathrm{B} 23$ \\
\hline
\end{tabular}

Table 3: Variable 3: Third Level KM Process

\begin{tabular}{|c|c|c|c|c|}
\hline Dimensions & Code Indicator & Indicator & Statement & $\begin{array}{l}\text { Inst } \\
\text { No. }\end{array}$ \\
\hline \multirow{2}{*}{$\begin{array}{c}\text { Co-creatin } \\
\mathrm{g} \\
\text { knowledge }\end{array}$} & \multirow{2}{*}{$\mathrm{C} 1$} & \multirow{2}{*}{$\begin{array}{c}\text { Creating } \\
\text { shared } \\
\text { knowledge }\end{array}$} & $\begin{array}{l}\text { Can join in existing online groups of discussions for the purpose of } \\
\text { created get knowledge }\end{array}$ & $\mathrm{C} 11$ \\
\hline & & & Active to share data and information within a group. & $\mathrm{C} 12$ \\
\hline \multirow{3}{*}{$\begin{array}{l}\text { Generating } \\
\text { knowledge }\end{array}$} & \multirow{3}{*}{$\mathrm{C} 2$} & \multirow{3}{*}{$\begin{array}{c}\text { Creating } \\
\text { new } \\
\text { knowledge }\end{array}$} & Active to provide innovation. & $\mathrm{C} 21$ \\
\hline & & & Provide ideas or ideas in troubleshooting. & $\mathrm{C} 22$ \\
\hline & & & Inviting others to contribute ideas and innovations. & $\mathrm{C} 23$ \\
\hline
\end{tabular}

Table 4: Variable 4: Employee Creativity

\begin{tabular}{|c|c|c|c|c|}
\hline Dimensions & Code Indicator & Indicator & Statement & $\begin{array}{l}\text { Inst } \\
\text { No. }\end{array}$ \\
\hline \multirow{2}{*}{$\begin{array}{l}\text { Co-creatin } \\
\mathrm{g} \\
\text { knowledge }\end{array}$} & \multirow[t]{2}{*}{$\mathrm{C} 1$} & \multirow{2}{*}{$\begin{array}{l}\text { Creating } \\
\text { shared } \\
\text { knowledge }\end{array}$} & $\begin{array}{l}\text { Can join in existing online groups of discussions for the purpose of } \\
\text { created get knowledge }\end{array}$ & $\mathrm{C} 11$ \\
\hline & & & Active to share data and information within a group. & $\mathrm{C} 12$ \\
\hline \multirow{3}{*}{$\begin{array}{l}\text { Generating } \\
\text { knowledge }\end{array}$} & \multirow{3}{*}{$\mathrm{C} 2$} & \multirow{3}{*}{$\begin{array}{l}\text { Creating } \\
\text { new } \\
\text { knowledge }\end{array}$} & Active to provide innovation. & $\mathrm{C} 21$ \\
\hline & & & Provide ideas or ideas in troubleshooting. & $\mathrm{C} 22$ \\
\hline & & & Inviting others to contribute ideas and innovations. & $\mathrm{C} 23$ \\
\hline
\end{tabular}

\section{RESULT AND DISCUSSIONS}

The following is the drawing result of research path along with indicators of each variable: (see Figure 2).

\subsection{Measurement Test Model (Outer Model)}

To conduct a model evaluation it is necessary to test validity and reliability of data. Validation of each manifest variable is determined by convergent validity and discriminant validity with latent variables, whereas the reliability of the data is determined based on the composite realibility value of each manifest variable block. Here is the result of PLS algorithm, shown in Figure 3.

In validity test conducted two kinds of testing that is convergent test validity and discriminant test validity.

\subsection{Convergent Validity Test}

According to (Ghozali 1., 2014) that individual indicators are considered reliable if it has a correlation above 0.70 , then 
from the calculation results there are 3 indicators that must be removed ie A21 (0.519), B11 (0.394), and B12 (0.519), shown in Table 5.
After deleting three indicators and recalculating it is found that all indicators have fulfilled the convergent validity. Base on Table 6 , the result of convergent validity test after done deletion of data.

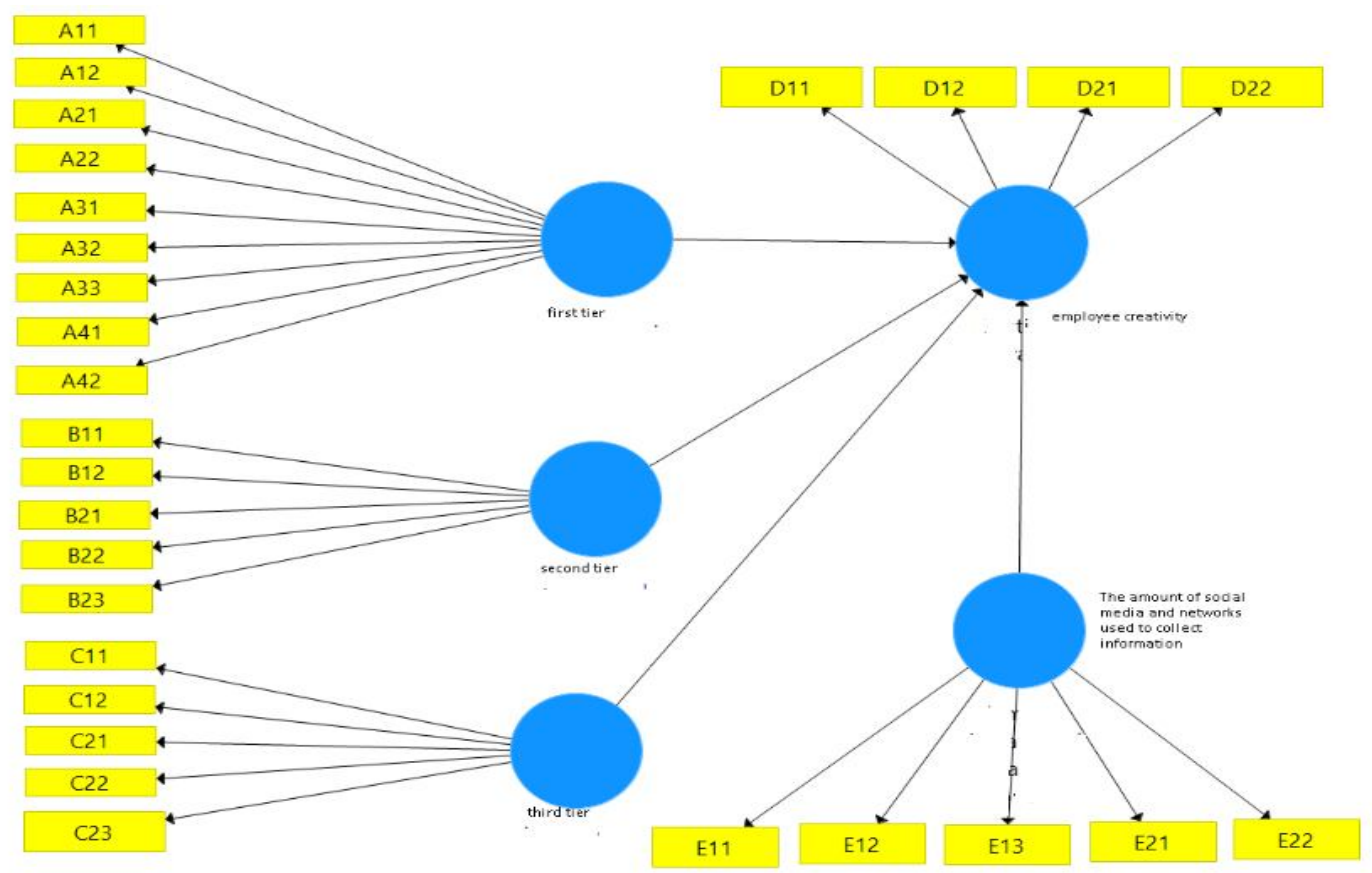

Figure 2: Initial Path Diagram

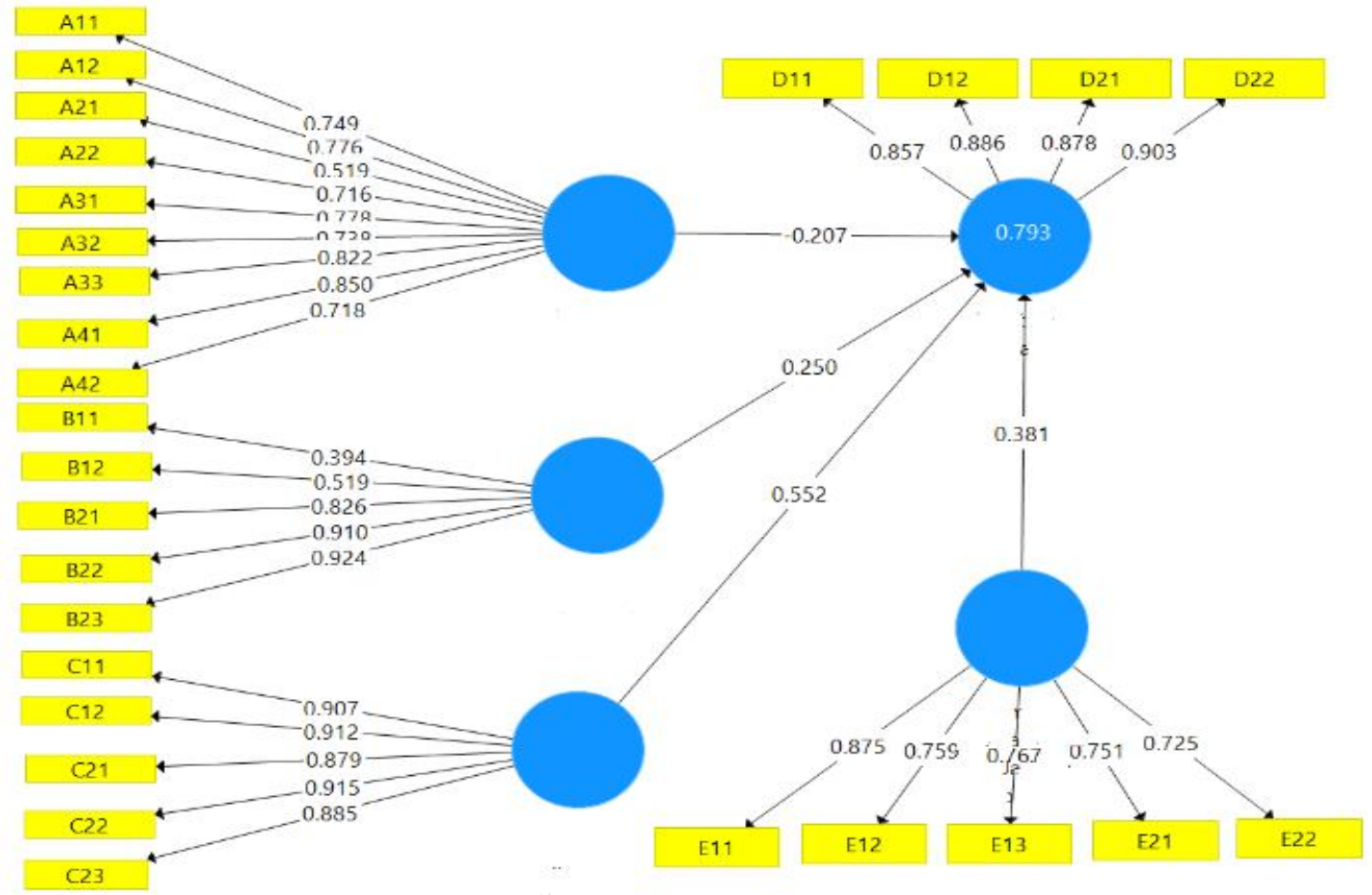

Figure 3: Preliminary Results Analysis of PLS Algorithm. 
Table 5: Output Line Diagram for Loading Factor

\begin{tabular}{|c|c|c|c|c|c|}
\hline & $\begin{array}{c}\text { Variable } \\
1 \\
\text { First tier }\end{array}$ & $\begin{array}{l}\text { Variable } 2 \\
\text { Second tier }\end{array}$ & $\begin{array}{c}\text { Variable } \\
\mathbf{3} \\
\text { Third tier } \\
\end{array}$ & $\begin{array}{c}\text { Variable } \\
4 \\
\text { Employee } \\
\text { creativity }\end{array}$ & $\begin{array}{c}\text { Variable } 5 \\
\text { Amount of } \\
\text { Social } \\
\text { Media } \\
\end{array}$ \\
\hline A11 & 0.749 & & & & \\
\hline A12 & 0.776 & & & & \\
\hline A21 & 0.519 & & & & \\
\hline A22 & 0.716 & & & & \\
\hline A31 & 0.778 & & & & \\
\hline A32 & 0.738 & & & & \\
\hline A33 & 0.822 & & & & \\
\hline A41 & 0.850 & & & & \\
\hline A42 & 0.718 & & & & \\
\hline B11 & & 0.394 & & & \\
\hline B12 & & 0.519 & & & \\
\hline B21 & & 0.826 & & & \\
\hline B22 & & 0.910 & & & \\
\hline B23 & & 0.924 & & & \\
\hline C11 & & & 0.907 & & \\
\hline C12 & & & 0.912 & & \\
\hline $\mathrm{C} 21$ & & & 0.879 & & \\
\hline $\mathrm{C} 22$ & & & $0 / 915$ & & \\
\hline $\mathrm{C} 23$ & & & 0.885 & & \\
\hline D11 & & & & 0.857 & \\
\hline D12 & & & & 0.886 & \\
\hline D21 & & & & 0.878 & \\
\hline D22 & & & & 0.903 & \\
\hline E11 & & & & & 0.875 \\
\hline E12 & & & & & 0.759 \\
\hline E13 & & & & & 0.767 \\
\hline E21 & & & & & 0.751 \\
\hline E22 & & & & & 0.725 \\
\hline
\end{tabular}

Table 6: Output Line Diagram after Deletion of 3 Indicators

\begin{tabular}{|c|c|c|c|c|c|}
\hline & $\begin{array}{c}\text { Variable } \\
1 \\
\text { First tier }\end{array}$ & $\begin{array}{l}\text { Variable } 2 \\
\text { Second tier }\end{array}$ & $\begin{array}{c}\text { Variable } \\
\mathbf{3} \\
\text { Third tier }\end{array}$ & $\begin{array}{c}\text { Variable } \\
4 \\
\text { Employee } \\
\text { creativity }\end{array}$ & $\begin{array}{c}\text { Variable } 5 \\
\text { Amount of } \\
\text { Social } \\
\text { Media }\end{array}$ \\
\hline A11 & 0.762 & & & & \\
\hline A12 & 0.762 & & & & \\
\hline A22 & 0.721 & & & & \\
\hline A31 & 0.768 & & & & \\
\hline A32 & 0.752 & & & & \\
\hline A33 & 0.838 & & & & \\
\hline A41 & 0.836 & & & & \\
\hline A42 & 0.706 & & & & \\
\hline B21 & & 0.855 & & & \\
\hline B22 & & 0.911 & & & \\
\hline B23 & & 0.941 & & & \\
\hline $\mathrm{C} 11$ & & & 0.907 & & \\
\hline $\mathrm{C} 12$ & & & 0.912 & & \\
\hline $\mathrm{C} 21$ & & & 0.879 & & \\
\hline $\mathrm{C} 22$ & & & 0.915 & & \\
\hline
\end{tabular}




\begin{tabular}{|l|c|l|c|c|c|}
\hline & $\begin{array}{c}\text { Variable } \\
\mathbf{1} \\
\text { First tier }\end{array}$ & $\begin{array}{c}\text { Variable 2 } \\
\text { Second tier }\end{array}$ & $\begin{array}{c}\text { Variable } \\
\mathbf{3} \\
\text { Third tier }\end{array}$ & $\begin{array}{c}\text { Variable } \\
\mathbf{4} \\
\text { Employee } \\
\text { creativity }\end{array}$ & $\begin{array}{c}\text { Variable 5 } \\
\text { Amount of } \\
\text { Social } \\
\text { Media }\end{array}$ \\
\hline C23 & & & 0.885 & & \\
\hline D11 & & & & 0.857 & \\
\hline D12 & & & & 0.887 & \\
\hline D21 & & & & 0.878 & \\
\hline D22 & & & & 0.903 & \\
\hline E11 & & & & & 0.875 \\
\hline E12 & & & & & 0.759 \\
\hline E13 & & & & & 0.767 \\
\hline E21 & & & & & 0.751 \\
\hline E22 & & & & & 0.725 \\
\hline
\end{tabular}

Table 7: AVE value

\begin{tabular}{|l|c|}
\hline Variable & Average Varience Extracted (AVE) \\
\hline Variable 1 & 0.595 \\
\hline Variable 2 & 0.810 \\
\hline Variable 3 & 0.815 \\
\hline Variable 4 & 0.777 \\
\hline Variable 5 & 0.604 \\
\hline
\end{tabular}

Tabel 8: Discriminant Validity Test

\begin{tabular}{|c|c|c|c|c|c|}
\hline & $\begin{array}{c}\text { Variable 5 } \\
\text { Amount of } \\
\text { Social } \\
\text { Media }\end{array}$ & $\begin{array}{c}\text { Variable } \\
\mathbf{4} \\
\text { Employee } \\
\text { creativity }\end{array}$ & $\begin{array}{c}\text { Variable } \\
\mathbf{3} \\
\text { Third tier }\end{array}$ & $\begin{array}{c}\text { Variable 2 } \\
\text { Second tier }\end{array}$ & $\begin{array}{c}\text { Variable } \\
\mathbf{1} \\
\text { First tier }\end{array}$ \\
\hline $\begin{array}{c}\text { Variable } \\
\mathbf{5}\end{array}$ & $\mathbf{0 . 7 7 7}$ & & & & \\
\hline $\begin{array}{c}\text { Variable } \\
\mathbf{4}\end{array}$ & 0.734 & $\mathbf{0 . 8 8 1}$ & & & \\
\hline $\begin{array}{c}\text { Variable } \\
\mathbf{3}\end{array}$ & 0.623 & 0.785 & $\mathbf{0 . 9 0 3}$ & & \\
\hline $\begin{array}{c}\text { Variable } \\
\mathbf{2}\end{array}$ & 0.634 & 0.839 & 0.796 & $\mathbf{0 . 9 0 0}$ & \\
\hline $\begin{array}{c}\text { Variable } \\
\mathbf{1}\end{array}$ & 0.738 & 0.691 & 0.745 & 0.758 & $\mathbf{0 . 7 7 2}$ \\
\hline
\end{tabular}

While the model image after removal of 3 index that don't fulfill the requirements of converging of validity test is.

Next is to judge the validity by looking for common or Average Variance Extraced (AVE) value, where latent variables should get a value greater than 0.50 if you want to get a good model (Ghozali 1. , 2014). From the data after the re-estimation that all variables already have value AVE $>0.05$, which are described in the table 7.

\subsection{Discriminant Validity test}

The model has discriminant validity is enough if the Average Variance Extraced (AVE) root for each build is greater than the relationship between construct and other construct (Ghozali 1. , 2014). Based on the test results shown in table 8 , the AVE value is higher than the other construct correlation so that the constructs in the model are estimated to meet Discriminant Validity.

\subsection{Validity Test}

To be able to declare that the reliable model then composite value reability and cronbach alpha must reach 0.70 . The composite Rebility composite results in which all composite reability values have exceeded 0.70 so it can be concluded that the constructs have good reability in Table 9. 
Table 9: Composite Reability Test Result

\begin{tabular}{|c|c|}
\hline & Composite Reability \\
\hline Variable 1 & 0.921 \\
\hline Variable 2 & 0.930 \\
\hline Variable 3 & 0.955 \\
\hline Variable 4 & 0.933 \\
\hline Variable 5 & 0.883 \\
\hline
\end{tabular}

Base on Table 10, this is similar to the Cronbach alpha calculation where the value already exceeds 0.70 so it may be concluded that the setup has nice reliability.

Table 10: Cronbach Alpha Test Results

\begin{tabular}{|l|c|}
\hline & Cronbach's Alpha \\
\hline Variable 1 & 0.903 \\
\hline Variable 2 & 0.886 \\
\hline Variable 3 & 0.941 \\
\hline Variable 4 & 0.904 \\
\hline Variable 5 & 0.838 \\
\hline
\end{tabular}

\subsection{Inner Model}

The next stage is structural model test process (Inner Model). At this stage, two measurement models are Coefficient of Determination $\left(\mathrm{R}^{2}\right)$ and Predictive Relevance $\left(\mathrm{Q}^{2}\right)$.

\subsection{Determination Coefficient $\left(\mathbf{R}^{2}\right)$}

Determination Coefficient Test $\left(\mathrm{R}^{2}\right)$ will be evaluated the structural model seen from the coefficient of determination $\left(\mathrm{R}^{2}\right)$. $\mathrm{R} 2$ results of $0.67,0.33$, and 0.19 for endogenous latent variables in the structural model indicate that the models are "nice", "so so", and "poor". From table 11 it can be seen that the endogenous variable of Employee Creativity can be explained by exogenous variables that influence it is $79.8 \%$ while $20.2 \%$ is explained by other variables, shown in Table 11.

Table 11: Coefficient of Determination Results $\left(\mathrm{R}^{2}\right)$

\begin{tabular}{|c|c|}
\hline & R Square \\
\hline Employee Creativity & 0.798 \\
\hline
\end{tabular}

The results show good entry because of the result $R^{2}>$ 0.67

\subsection{Predictive Relevance (Q2)}

Q-Square is done to evaluated how well the observation value generated by the model and also its parameter calculation. To get the value of $\mathrm{Q}^{2}$ (Predictive Relevance) can use the formula:

$\mathrm{Q}^{2}=1-\left(1-\mathrm{R} 1^{2}\right)\left(1-\mathrm{R} 2^{2}\right) \ldots . .\left(1-\mathrm{Rp}^{2}\right)$

So from the formula obtained calculation:

$$
\begin{aligned}
\mathrm{Q}^{2} & =1-(1-0.637) \\
& =1-0.363 \\
& =0.637
\end{aligned}
$$

From the calculation result $\mathrm{Q}^{2}>0$ to show that the model has predictive relevance and it may be concluded that the model is nice.

\subsection{Hypothesis testing (Resampling Bootsraping)}

Base on Figure 1, after testing then hypothesis tested (resampling bootstrapping), in the rule of tumbs from supporting a research hypothesis consists of: (1) if the coefficient or direction of the relation variable (addressed by the genuine sample value) is in line with the hypothesized, and (2) if the statistical $t$ value is more over 1.64 (two-tiles) or 1.96 (one-tiles) and the probability value (p-value) is less than 0.05 or $5 \%$.

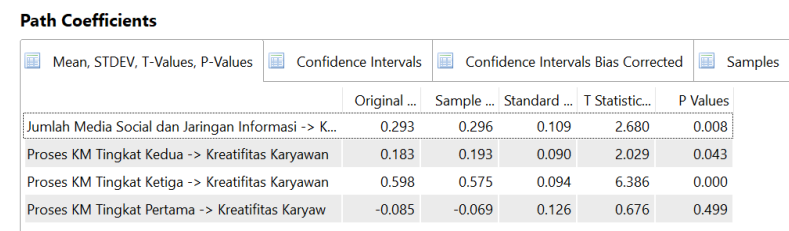

Figure 4. Final Result from Path Coefficient

Here is the explanation for each hypothesis:

a. $\mathrm{H}_{1}$. The social media (SM) use for first-tier Knowledge Management (KM) processes (ie searched, stored and categorized of information) is positively connect to employee creativity (EC).

Based on Figure 4 shows that the $\mathrm{p}$ values obtained are 0.499 which is greater than 0.05 , so it can be concluded that Social Media usage factor for first level Knowledge Management (KM) process (ie searched, stored and categorized of information) has no effect on employee creativity factor, H1 Hypothesis Rejected.

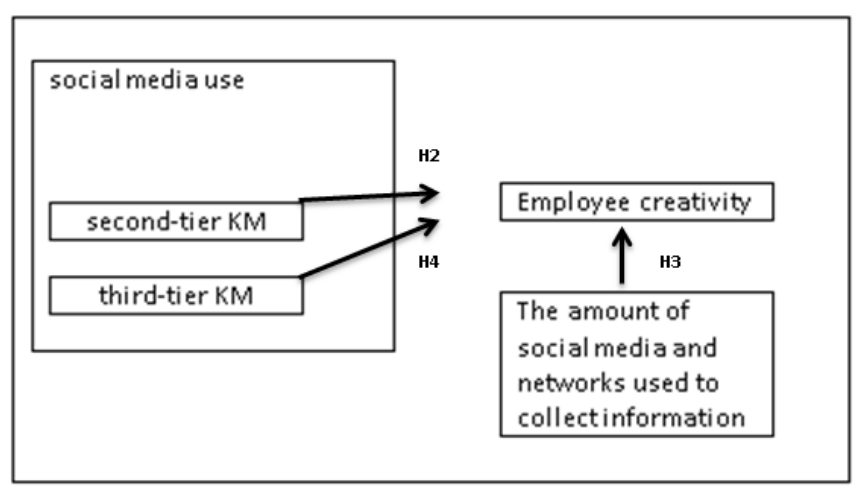

Figure 5: Final Model

b. $\mathrm{H}_{2}$. The social media (SM) use for second-tier knowledge management (KM) processes (ie accessed and debated of information with others people) is positively related to employee creativity (EC).

Based on Figure 4 shows that the $\mathrm{p}$ values obtained are 0.043 which is smaller than 0.05 , so it can be concluded that Social Media usage factor for second level KM 
process (ie accessing and debating information with others) has a positive effect on employee creativity factor, H2 Hypothesis Accepted.

c. $\mathrm{H}_{3}$. The amount of social media (SM) and networks used to collect or discuss information positively corelation to employee creativity (EC).

Based on Figure 4 shows that the $\mathrm{p}$ values obtained for 0.08 which is smaller than 0.05 , so it can be concluded that the factor The amount of social media (SM) and network used to collect or discuss information positively affect the creativity of employees, H3 Hypothesis Accepted.

d. $\mathrm{H}_{4}$. The social media (SM) use for third-tier knowledge management $(\mathrm{KM})$ processes (ie creating and producing knowledge) is positively related to employee creativity (EC).

Based on Figure 4 shows that the $\mathrm{p}$ values obtained are 0.00 which is smaller than 0.05 , so it can be concluded that Social Media usage factor for third level knowledge management (KM) process (ie created and produced of knowledge) has a positive corelation on employee creativity (EC), H4 Hypothesis Accepted.

From hypothesis result calculation hence got final model: (see Figure 5: Final Model)

\section{CONCLUSION}

From the research results can be concluded that the SM use for second-level knowledge management process, the amount of SM and network used to collect or discuss information, The social media use for third-level knowledge management process can affect the creativity of employees who have background work in the field of information technology.

\section{REFERENCES}

[1] D. Nedbal, A. Auinger, and A. Hochmeier. Addressing Transparency, Communication and Participation in Enterprise 2.0 Projects, Procedia Technol., vol. 9, pp. 676-686, 2013. https://doi.org/10.1016/j.protcy.2013.12.075

[2] I. S. Makki, F. Alqurashi. An Adaptive Model for Knowledge Mining in Databases “EMO_MINE" for Tweets Emotions Classification, International Journal of Advanced Trends in Computer Science and Engineering, Vol. 7, No. 3, 2018. https://doi.org/10.30534/ijatcse/2018/04732018

[3] E. Forcier, D. Rathi, and L. M. Given. Knowledge Management and Social Media: A Case Study of Two Public Libraries in Canada, J. Inf. Knowl. Manag., vol. 12, no. 4, p. 1350039, 2013. https://doi.org/10.1142/S0219649213500391

[4] S. Papagiannidis and M. Bourlakis. Special Issue Theme: 'Social Media: A revolution in communication'. Technological Forecasting \& Social Change," Technol. Forecast. Soc. Change, vol. 95, pp. 1-2, 2015.

https://doi.org/10.1016/j.techfore.2014.09.011
[5] D. L. Roberts and M. Candi. Leveraging social network sites in new product development: Opportunity or hype?, J. Prod. Innov. Manag., vol. 31, no. S1, pp. 105-117, 2014. https://doi.org/10.1111/jpim.12195

[6] M. Sigala and K. Chalkiti. Knowledge management, social media and employee creativity, Int. J. Hosp. Manag., vol. 45, pp. 44-58, 2015.

[7] S. Panahi, J. Watson, and H. Partridge. Social Media and Tacit Knowledge Sharing: Developing a Conceptual Model, Eng. Technol., vol. 64, no. 4, pp. 1095-1102, 2012.

[8] A. Patel and S. Jain. Formalisms of Representing Knowledge, Procedia Comput. Sci., vol. 125, pp. 542-549, 2018. https://doi.org/10.1016/j.procs.2017.12.070

[9] Y. Hwang, H. Lin, and D. Shin. Knowledge system commitment and knowledge sharing intention: The role of personal information management motivation, Int. J. Inf. Manage, vol. 39, no. August 2017, pp. 220-227, 2018.

[10] M. J. Marques et al. Multifaceted impacts of sustainable land management in drylands: A review, Sustain., vol. 8, no. 2, 2016.

[11] Y. Uchiyama, H. Matsuoka, and R. Kohsaka. Apiculture knowledge transmission in a changing world: Can family-owned knowledge be opened?, J. Ethn. Foods, vol. 4, no. 4, pp. 262-267, 2017. https://doi.org/10.1016/j.jef.2017.09.002

[12] F. Giunchiglia, M. Zeni, E. Gobbi, E. Bignotti, and I. Bison. Mobile social media usage and academic performance, Comput. Human Behav., vol. 82, pp. 177-185, 2018.

[13] C. Nicolas Alarcón, A. Urrutia Sepúlveda, L. Valenzuela-Fernández, and J. Gil-Lafuente. Systematic mapping on social media and its relation to business, Eur. Res. Manag. Bus. Econ., vol. 24, no. 2, pp. 104-113, 2018.

https://doi.org/10.1016/j.iedeen.2018.01.002

[14] I. Lee. Social media analytics for enterprises: Typology, methods, and processes, Bus. Horiz., 2017.

[15] Z. Gaál, L. Szabó, N. Obermayer-Kovács, and A. Csepregi. Exploring the Role of Social Media in Knowledge Sharing, Electron. J. Knowl. Manag., vol. 13, no. 3, pp. 185-197, 2014.

[16] F. O. Omotayo. Knowledge Management as an important tool in organisational management: A review of literature, Libr. Philos. Pract. (e-journal)., vol. 1238, pp. 1-23, 2015.

[17] N. Mahmud and S. M. Drus. A Review of Knowledge Management Implementation Through Cloud Computing in Malaysia, no. 118, pp. 621-627, 2017.

[18] R. Helms, M. A. De Kok, and B. Bellefroid. The new way of knowledge sharing, p. 113, 2012.

[19] J. Hemsley and R. M. Mason. The Nature of Knowledge in the Social Media Age: Implications for Knowledge Management Models, 2012 45th Hawaii Int. 
Conf. Syst. Sci., pp. 3928-3937, 2012.

[20] G. Avram. At the Crossroads of Knowledge Management and Social Software, J. Knowl. Manag., vol. 4, no. 1, pp. 1-10, 2006.

[21] A. Zehrer. Knowledge management in tourism - the application of Grant's knowledge management model to Austrian tourism organizations, Tour. Rev., vol. 66, no. 3, pp. 50-64, 2011.

[22] A. Mardani, S. Nikoosokhan, M. Moradi, and M. Doustar. The Relationship Between Knowledge Management and Innovation Performance, J. High Technol. Manag. Res., vol. 29, no. 1, pp. 12-26, 2018. https://doi.org/10.1016/j.hitech.2018.04.002

[23] S. M. M. Jad et al., "The relationship between knowledge of leadership and knowledge management practices in the food industry in Kurdistan province, Iran," Data Br., vol. 15, pp. 155-159, 2017.

[24] A. Miklosik and S. Zak. Framework for Effective Removal of Knowledge Management Implementation Barriers, Procedia Econ. Financ., vol. 30, no. 15, pp. 513-521, 2015.

[25] M. - E. Boatca, A. Draghici, and N. Carutasu. A Knowledge Management Approach for Ergonomics Implementation within Organizations, Procedia - Soc. Behav. Sci., vol. 238, pp. 199-206, 2018. https://doi.org/10.1016/j.sbspro.2018.03.024

[26] Y. Xin, V. Ojanen, and J. Huiskonen. Knowledge Management in Product-Service Systems - A Product Lifecycle Perspective, Procedia CIRP, vol. 0, no. May, pp. 29-31, 2018.

[27] X. Zhang, Y. Gao, X. Yan, P. O. de Pablos, Y. Sun, and $X$. Cao. From e-learning to social-learning: Mapping development of studies on social media-supported knowledge management, Comput. Human Behav., vol. 51, 2015.

[28] K. Tomczak-Horyń and R. Knosala. Evaluation of Employees' Creativity as a Stimulator of Company Development, Procedia Eng., vol. 182, pp. 709-716, 2017. https://doi.org/10.1016/j.proeng.2017.03.184

[29] B. Krstić and B. Petrović. The Role of Knowledge Management in Increasing Enterprise'S Innovativeness, Econ. Organ., vol. 9, no. 1, pp. 93-110, 2012.

[30] R. Gupta and B. Bajaj. The Relationship between Leader's Emotional Intelligence and Employee Creativity: A Conceptual Framework of Mechanism, Procedia Comput. Sci., vol. 122, pp. 471-477, 2017.

[31] M. Pieri and D. Diamantini,. An E-learning Web 2.0 Experience, Procedia - Soc. Behav. Sci., vol. 116, pp. 1217-1221, 2014.

[32] G. Corral de Zubielqui, H. Fryges, and J. Jones. Social media, open innovation \& HRM: Implications for performance, Technol. Forecast. Soc. Change, no. March 2016, 2017.

[33] M. B. Carnicer. The Use of Educational Data Mining Technique in Technology Assimilation Evaluation: A
Response Assessment. International Journal of Advanced Trends in Computer Science and Engineering, Vol. 8, No. 3, 2019.

[34] B. Zheng, H. Liu, and R. M. Davison. Exploring the relationship between corporate reputation and the public's crisis communication on social media, Public Relat. Rev., vol. 44, no. 1, pp. 56-64, 2017. https://doi.org/10.1016/j.pubrev.2017.12.006

[35] R. Rauter, D. Globocnik, E. Perl-Vorbach, and R. J. Baumgartner. Open innovation and its effects on economic and sustainability innovation performance, J. Innov. Knowl., 2018.

[36] V. A. Chavez, R. Stinnett, R. Tierney, and S. Walsh. The importance of the technologically able social innovators and entrepreneurs: A US national laboratory perspective, Technol. Forecast. Soc. Change, vol. 121, pp. 205-215, 2017. https://doi.org/10.1016/j.techfore.2016.09.002

[37] R. P. J. Rajapathirana and Y. Hui. Relationship between innovation capability, innovation type, and firm performance, J. Innov. Knowl., vol. 3, no. 1, pp. 44-55, 2017.

https://doi.org/10.1016/j.jik.2017.06.002 